\title{
Attitudes and Motivation in Early Foreign Language Learning
}

Jelena Mihaljević Djigunović ${ }^{1}$

$\approx \quad$ This paper focuses on young foreign language learners' attitudes and motivations. An overview is given of the main issues in this research area, based on key European studies. Approaches to studying these affective learner characteristics are described. Some attention is devoted to data elicitation techniques and the importance of triangulation. Research findings are presented through overviews of cross-sectional and longitudinal studies carried out in different European settings. The latter are presented in more detail, because their findings seem to be more revealing of the early foreign language learning process. The overall conclusion of this review paper is that young foreign language learners' attitudes and motivations are not stable learner characteristics but change over time, creating layers of complexity that warrant further research. Suggestions about possible future directions in researching young foreign language learner attitudes and motivations, and the application of its findings are also made.

Keywords: attitudes, early foreign language learning, motivation, young learner 


\section{Odnos in motiviranost mlajših učencev do učenja tujega jezika}

Jelena Mihaljević Djigunović

$\propto$ Osrednji temi prispevka sta odnos mlajših učencev za učenje tujih jezikov in njihova motivacija. Na osnovi ključnih evropskih raziskav je pripravljen pregled glavnih problemov na tem področju. Za potrebe proučevanja so predstavljene emocionalne karakteristike učencev. Nekaj pozornosti je namenjene predstavitvi podatkov in pomembnosti triangulacije. Pregledno so predstavljeni izsledki medpodročnih in longitudinalnih raziskav, opravljenih $\mathrm{v}$ različnih evropskih skupinah. Longitudinalne raziskave so predstavljene podrobneje, saj kaže, da nam te dajo več podatkov/spoznanj o učnih procesih pri zgodnjem učenju tujih jezikov. Temeljno spoznanje preglednega prispevka, da odnos mlajših učencev za učenje tujih jezikov in njihova motivacija nista stabilni lastnosti, ampak se s časom spreminjata, ustvari idejo kompleksnosti problema, ki ga je treba še naprej raziskovati. Dani so tudi predlogi usmeritev nadaljnjih raziskav odnosa in motivacije mlajših učencev za učenje tujih jezikov ter predlogi uporabe izsledkov raziskav.

Ključne besede: odnosi, zgodnje učenje tujega jezika, motivacija, mlajši učenci 


\section{Introduction}

\section{Defining the young language learner}

In different socio-educational contexts, the term young learners refers to different age ranges. The European Union member states working group has recently defined young learners as primary school pupils between the ages of seven and 12, and has introduced the term very young learners to refer to preschoolers (age: three to six years). Still, in some contexts even learners older than 12 are often included in the young learners' age group, reflecting different national policies and practices in introducing children to foreign language (FL) learning.

\section{General developments in studying young learner affective characteristics}

Research into young foreign language learners' affective characteristics carried out in the European context reveals very interesting trends. For quite a long time, studies on affective learner factors included mostly more mature learners: it was believed that young learners are so similar to one another that investigations of such individual difference variables would not be informative at all. According to popular belief, all children are highly motivated to learn FLs, have very positive attitudes and no inhibitions, and are successful by default. MacIntyre, Baker, Clément and Donovan (2002) warn, however, that young learners vary among themselves just as more mature learners do, and that research into young learners' individual differences is necessary.

Although investigations of attitudes and motivation in FL learning have, generally speaking, a long tradition (e.g., Dörnyei, 1990; Gardner \& Lambert, 1959, 1972; Nikolov, 2002; Vilke, 1979), the beginnings of such investigations with young FL learners were not that simple. The existing instruments were more suited to older learners and could not be automatically used with children: they first had to be adapted to become age-appropriate, or completely new ones had to be designed for the purpose.

Although attitudes and motivation are two distinct individual learner factors, they are considered to be closely inter-related and are often investigated together. While language attitudes refer to positive or negative feelings about a language and what the learner may connect it with (Gardner \& MacIntyre, 1993), Gardner $(1985,2010)$ defines motivation as a combination of the desire to learn the language, positive attitudes to learning the language, and the effort invested in learning. An analysis of the attitudinal and motivational studies with young learners to date suggests that they have been done from different 
perspectives and have started from different premises. Until quite recently, attitudes and motivation were considered in terms of their relationship with learner achievement and discussed as the cause of learning success (e.g., Burstall, 1975; Vilke, 1979). However, more recently some researchers (e.g., Blondin et al., 1998; Edelenbos, Johnstone, \& Kubanek, 2007) have emphasised that we should really be looking at attitudes and motivation as an aim and a result of early FL learning. This has contributed to the more refined approaches that can be observed in recent years. On the one hand, attitudes and motivation are not any more necessarily viewed as single variables in relation to learning outcomes, but they are often considered to be interacting with other individual learner variables, such as language aptitude, language anxiety, language learning styles and strategies, and the like. On the other hand, the contextual factors (e.g., the immediate learning environment, learners' socio-economic status, language exposure outside school) came to be included in recent studies. It can also be observed that the developmental aspect of attitudes and motivation is gaining importance (e.g., Mihaljević Djigunović \& Lopriore, 2011; Nikolov, 2002). This temporal dimension reveals the dynamics of young learners' affective development, which opens up the layers of complexity that characterises early FL learning.

In the following sections, we will look into all of the listed perspectives and present the insights into young FL learners' attitudes and motivation that research carried out in the European context to date has provided.

\section{Eliciting data on attitudes and motivation of young language learners}

Researching young learners' attitudes and motivation is rather complex. Children sometimes find it hard to articulate their thoughts, perceptions and feelings. Therefore, it is essential that appropriate instruments and procedures are used. Another problem emerges if data collection is based only on selfreports. As pointed out by Pinter (2011), what young learners may report they think or feel often contradicts what they do in the classroom. Thus, triangulation is highly important in researching their affective characteristics. Still, young learners have been observed to be a very valuable source of information on early FL learning (Enever, 2011; Nikolov, 2002).

As in studies with older learners, questionnaires are often used to collect information on young learners' attitudes and motivation. With younger children these are usually smiley questionnaires (Szpotowicz, Mihaljević Djigunović, \& Enever, 2009). They are age-appropriate for young learners 
because they include visual scales that children easily relate to: according to how they feel about the language learning aspect in question, children choose a sad smiley, an indifferent smiley or a happy smiley. Sometimes, questionnaires that were originally not meant for a particular age group are adapted for young learners, as was done with Attitudes/Motivation Test Battery (Gardner, 1985 ) for the purpose of the Irish primary modern languages project (Harris \& Conway, 2002). In some studies, questionnaires are designed for measuring the attitudes and motivation for FL learning in a particular context (Mihaljević Djigunović, 1998), because these variables are context-sensitive.

Interviews are used for more in-depth investigation of individual learners. They offer a possibility of probing deeper into affective aspects of early FL learning. For example, in Mihaljević Djigunović and Lopriore (2011), young learners were asked the "why questions" and provided very relevant information on why they preferred some classroom activities and why they disliked others. Sometimes information needs to be elicited in a more indirect way. In the study referred to above, data on learners' attitudes to teaching and learning FLs were elicited in such an indirect way: young learners were presented with four pictures of FL classrooms depicting different classroom arrangements (traditional, group work, sitting in a circle on the floor, chaotic) and asked in which of the four classrooms they would learn their FL best.

Classroom observation of young learners' language learning behaviour has been shown to complement data elicited by other techniques. Thus, a comparison of information elicited by smiley questionnaires and oral interviews with observation of young learners' interest, attention and engagement during particular activities showed a discrepancy between the data (Mihaljević Djigunović, 2009, March). Different behavioural patterns seemed to be characteristic for different classroom activities and at different points. Such insights are extremely relevant for understanding the relationship between attitudes and motivation, and young learners' language achievement.

\section{Insights into young learners' attitudes and motivation}

Investigations of young learners' affective characteristics have usually been carried out not as the main research focus but as one of the several foci within early FL learning studies. Most such studies have been cross-sectional, but the longitudinal approach has also been gaining in importance. Both quantitative and qualitative studies have been done, but the mixed-method or multiple-method approach (MacKey \& Gass, 2005) is now considered the most informative. 


\section{Findings of cross-sectional studies}

Cross-sectional studies have mostly aimed at describing young learners' current attitudes, determining the type and level of their motivation, and looking into their relationship with language achievement or some other individual learner factor.

In earlier studies, attitudes and motivation were investigated as if they were a stable variable. Thus, some authors (e.g., Mihaljević Djigunović, 1998) tried to determine types of learner motivation in a particular FL learning context, while others (e.g., Limić, 1983; Olshtain, Shohamy, Kemp, \& Chatow, 199o) attempted to determine the level of young learners' integrative or instrumental motivation. Such information, however, tapped into such generalised aspects of motivation that had little explanatory power for explaining early FL learning.

Interest in age-related differences in attitudes and motivation of European young learners produced a number of interesting studies. Some researchers (e.g., Chambers, 2000; Nikolov, 1999) observed that younger learners are characterised by more positive attitudes than older beginners. Others (e.g., Lasagabaster, 2003; Williams, Burden, \& Lanvers, 2002) did not establish significant differences that would be age related. Julkunen and Borzova (1996) obtained mixed results. As pointed out earlier, differences are sometimes due to applying different instruments or to using different research designs, but they also signal that the relationship of attitudes and motivation with achievement is complex, with many variables intervening. This is corroborated by findings of Tragant (2006), who concluded that an earlier start needs to be coupled with intensive teaching to result in more positive attitudes and higher motivation.

Some studies focused on whether the attitudes and motivation of young learners differ with respect to the FL being learned. Thus, large-scale studies carried out in Hungary (Nikolov, 2007, February; Nikolov \& Csapó, 2002; Nikolov \& Józsa, 2003, 2006) showed that learners of English had more positive attitudes than learners of German. Another, nationwide, Hungarian study (Dörnyei, Csizér, \& Németh, 2006), compared attitudes and motivation of learners of English, French, German, Italian and Russian and revealed that differences in attitudes and motivation differed with the regions: learners had more positive attitudes to and were more motivated for learning those languages that were traditionally geographically closer to them; that is, they were more positively inclined to the language that was spoken as $\mathrm{L}_{1}$ in their local region (e.g., German in the west of Hungary, or Russian in the east of the country). In Croatia, interesting results were found when comparing learners of English and German (Mihaljević Djigunović \& Bagarić, 2007). Learners of English 
were more motivated than learners of German, had more positive attitudes to the FL and its cultures as well as attitudes to themselves as learners. The authors explain these differences by referring to the observed differences in approaches to teaching the two languages in schools, in the different status they enjoy in society, and the fact that teachers of German have a more difficult job when it comes to motivating learners to learn.

The relationship of attitudes and motivation of young FL learners and learning conditions is a largely under-researched area. In one such uncommon study, Mihaljević Djigunović (2009) compared a group of Croatian first grade learners of English who learned this language under highly favourable conditions (small groups, intensive teaching, appropriately trained teachers) with a group that was exposed to regular conditions (big groups, only two hours of English per week, teachers of various competences and not trained specifically to work with young learners). The findings showed a less positive outlook on learning English, lower self-confidence and less enjoyment of English classes in the group that learned under less favourable conditions. Interestingly, however, even these latter ones believed it was a good idea to learn English, because they considered it a language of international communication. This indicates that the status of a language may override the impact of the learning conditions. It would be interesting to look into the impact of learning conditions in case of other FLs.

Most research looking into the association of attitudes and motivation with language achievement points to significant positive relationships. Thus, Harris and Convey (2002) found a positive relationship among Irish young learners of French, German and Italian. Bernaus, Cenoz, Espí and Lindsay (1994, as cited in Tragant, 2006, p. 241) found consistently positive correlations between motivation and learning outcomes in learners as young as four. Positive relationships were also found for young learners of differing ages by Bagarić (2007), Dörnyei, Csizér and Németh (2006) and Mihaljević Djigunović (2007). High goal setting in learning English and German was observed to be connected with higher FL outcomes by Csapó and Nikolov (2002, April), Nikolov (2003, as cited in Nikolov, 2007, February), Nikolov and Csapó (2002) and Nikolov and Józsa (2003, 2006). In spite of these unambiguous results, it has been observed that the relationship between attitudes and motivation and learning achievement can be quite complex. Some studies (e.g., Grahan, 2004; Masgoret \& Gardner, 2003; Tragant \& Muñoz, 200o) revealed that strong correlations become weaker as the learner's age increases, suggesting that new and different interactions become more relevant as young FL learners become more mature. 


\section{Findings of longitudinal studies}

While cross-sectional research is by nature product-oriented, longitudinal studies are focused on processes. Their findings help us better understand how the language learning process develops over time and reveal its dynamics. Such studies are infrequently performed, because they are highly complex to carry out.

In this section, we will first give an overview of the main findings and then present in greater detail three European longitudinal studies that, in our opinion, are particularly interesting from the point of view of design, scope, findings or impact.

Most studies focusing on young learners' attitudes suggest that they generally adopt attitudes of their parents, siblings, friends, and teachers, i.e. people who can be considered as their significant others (e.g., Low, Brown, Johnstone, \& Pirrie, 1995; Nikolov, 2002; Szpotowicz, Mihaljević Djigunović, \& Enever, 2009). Interestingly, Vilke (1979) found that this influence also can go in the opposite direction: in her experimental project about the optimal age to start FL learning the parents' negative or neutral attitudes to early FL learning at the start became positive after seeing the enthusiasm for FL classes and the enjoyment that their children displayed during the project. Once they accumulate some first-hand experiences in FL learning, young learners have been found to develop their own attitudes. Nikolov $(1999,2002)$ found that these are shaped by classroom processes. The role of the FL teacher has been shown as crucial (Vilke, 1993) for both attitude formation and maintaining motivation. Marschollek (2002), however, found that contact with native speakers contributed to the development of positive attitudes to FL learning.

\section{The Pécs project (1977-1995)}

The Pécs project (Nikolov, 2002) involved three generations of Hungarian young learners of English who were followed throughout eight years of primary school. This longitudinal project started in 1977 and ended in 1995. Although the main aim was to develop an English syllabus for primary children, it necessarily included investigations of children's attitudes and motivation. What is unique about this project is that the researcher and the teacher were the same person, which allowed close and in-depth longitudinal tracking of young learners' attitudes and motivation over substantial periods of time.

The 84 participants belonging to three generations were, each year, first administered a questionnaire containing the same six open-ended questions. The questions elicited information on the children's most and least favourite school subjects, on why they learned English, what they liked and disliked about 
their English classes, and on what they would do differently if they were the teacher. This was regularly followed by a discussion in which the children could openly express their own opinions and could make suggestions for changes. The findings showed very positive attitudes to English classes as a learning context. The results concerning the children's motivational orientation revealed that the participants' motivation stemmed from their classroom experience and from the teacher as a distinct source of motivation, and was also based on such external reasons as the family, and utilitarian reasons, such as possibility of practical use of English. Analysis of the children's answers according to similarities and differences led Nikolov to establishing three broad developmental phases that corresponded to three age subgroups: the youngest involved the children at ages of 6-8 years, the second phase referred to age range of 8-11 years and the third one was 11-14 years of age. The youngest learners reported liking English classes because they were fun and easy for them, they got rewards for correct answers, and they felt they were good at English. They also liked their teacher because she was nice; they felt she loved them, and that she was short and long-haired (!). In this first phase, the young learners also liked the fact that some members of their family learned English and that they themselves could also teach their family some English. A few learners liked learning English because their mother told them it would be useful if they went abroad. In the middle phase, the classroom experience and teacher-related explanations were still very prominent, though some of the emphases were a bit different (e.g., classes were reported as not boring, learners could do what they pleased, the teacher did not shout and was not angry). The frequency of external reasons increased, and changed in nature: for example, learners were now reporting they learned English because their parents signed them up. Utilitarian reasons (usefulness of English knowledge) also increased in frequency and reflected future orientation (e.g., English would be useful in future travels). While classroom experience reasons were still often mentioned, in the third phase the frequency of teacher-related reasons decreased, the external reasons were reported rarely and the utilitarian reasons prevailed. A comparison of the three phases shows that, generally, classroom experience-related reasons remained important throughout the three phases giving evidence of the existing intrinsic motivation for learning English, with teacher-related reasons becoming less frequent from the second phase onward. The utilitarian reasons consistently increased and reached its peak in the third phase. Some, though not very defined, instrumental-knowledge motivational orientation and linguistic self-confidence (Clément, Dörnyei, \& Noels, 1994) emerged before puberty and became salient around puberty, while evidence of integrative motivation was absent. 
In her conclusion, Nikolov (2002) points out that the FL classroom provides a more relevant framework for studying young learners' attitudes and motivation than the one offered by second language acquisition research. Her findings offer convincing evidence that motivational factors in early FL learning rely on positive classroom experience (intrinsically motivating activities, materials and tasks) and emotional bonds with the teacher, with knowledge increasingly replacing rewards and approval as external motivators.

\section{The Zagreb project (1991-2001)}

This longitudinal study also included following three generations of young learners from Grade 1 until the end of primary education (Grade 8). What is specific and unique about this project is that it involved parallel investigations of early learning of four foreign languages: English, French, German and Italian (Vilke \& Vrhovac, 1993, 1995; Vrhovac, 1999, 2001). The whole sample comprised over 1,200 young learners. The research team, led by Mirjana Vilke, worked in close cooperation with practising teachers who were teaching the FLs in the project schools. The main aims of the project were to describe the FL learning process during the primary years and to determine whether the first year of formal education in Croatia (Grade 1 of primary school) was the optimal starting age for learning a FL on the national basis. The FL learning process was followed parallelly in the project children and control groups of learners who started with their FL in Grade 4 (age 10), which at the time was the regular, prescribed starting age. The project children had five lessons of the FL in the first two grades, four in Grades 3 and 4, and three from Grade 5 onward. They worked in groups consisting of up to 15 pupils and were taught by qualified teachers who had been additionally trained to teach young learners. The control group children had three lessons per week, worked in large groups and their teachers were not specifically trained to work with children.

Attitudinal and motivational development was measured at different points: in Grades 1, 3, and 8. During the first two times a specially designed interview was used; a questionnaire was administered the third time. Due to technical problems, not all cohorts participated in all data collections. The Italian cohort took part only in the first interview, and the questionnaire was administered only to learners of English. The interview consisted of 22 questions eliciting information on attitudes to the FL and its native speakers, to starting early, to the learner's self-perception of language achievement, and information on the perceived purposes of learning the FL. On the following data collection point, a questionnaire (Mihaljević Djigunović, 1998) was used. It was designed taking into account the Croatian socio-educational context. There were 38 items accompanied by 5-point 
Likert type scales. The questionnaire measured the following types of motivation: pragmatic-communicative (using English for pragmatic purposes and to communicate with foreigners), integrative (wishing to become a member of an English L1 group) and affective (wishing to know English because it is a beautiful, interesting and easy language). Two demotivators were included as well: the teaching setting demotivator and the language learning difficulties demotivator. The results (Mihaljević Djigunović \& Vilke, 200o) showed that initial attitudes were very positive among learners of all four FLs. All learners reported liking the FL and enjoying both playing and teaching activities. Compared to learners of the other three FLs, most learners in the Italian cohort (interestingly) preferred teaching over playing activities. In most cases, the learners' motivational orientation referred to communication with native speakers, or any foreigners, and travel but more general reasons were also observed (it is good to know things, FL knowledge increases one's general knowledge). By the end of Grade 3, positive attitudes and high motivation were still present in young learners of all the four languages. Generally speaking, they were maintained over an extended period of time. Young learners' preferences by now were less restricted to playing classroom activities and extended to teaching activities as well. Some differences in Grade 3 were observed in motivational orientations among learners of different FLs. Learners of English mentioned the communicative and travel orientations more frequently than in Grade 1, in contrast to learners of French and German who reported such orientations less frequently. Language features (ease of learning, usefulness) as well as future pragmatic benefits in terms of educational and job opportunities figured less prominently in all groups. Attitudes to native speakers, which were mostly positive in Grade 1, showed some changes by Grade 3. A high increase in positive attitudes to native speakers was observed in learners of English and French, while this increase was not significant among learners of German. Scores on the questionnaire administered to learners of English in Grade 8 suggest that by end of primary school young learners develop different types of motivation (Mihaljević Djigunović, 1998). The pragmatic-communicative type seemed to be the strongest, while the means for the integrative type were the lowest.

\section{The Early Language Learning in Europe (ELLiE) ${ }^{2}$ project (2006-2010)}

This trans-national longitudinal project started with a scoping year ${ }^{3}$ before becoming a three-year European Commission study (Enever, 2011). Its unique feature is that it followed young FL learners in seven different country

2 This research was supported by a European Commission grant under the Lifelong Learning Programme, Project no. 135632-LLP-2007-UK-KA1SCR. An additional British Council grant supported the Croatian team.

3 The scoping year was partly sponsored by the British Council. 
contexts: Croatia, England, Italy, the Netherlands, ${ }^{4}$ Poland, Spain and Sweden. Over 1,400 children were included. They were all learning English except for participants from England, where learners of French and Spanish were focused on. The main aim of the project was to get an insight into what can realistically be achieved through early FL learning in regular state schools in Europe. The project was very broad in terms of the variables included, and one of the research threads were attitudes and motivation.

The instruments used to tap into attitudes and motivation throughout the four years were smiley questionnaires, oral learner interviews, learner observation schedules and parents' questionnaire. Information was elicited on young learners' attitudes to FL learning and teaching, on preferences for classroom activities, motivated language learning behaviour and learner self-concept. Triangulation was secured through eliciting data on the same aspect from different sources (e.g., the children themselves and their parents) and through administering different instruments to probe the same aspects (e.g., smiley questionnaire and oral interview). As in the two longitudinal projects described above, young learners were also an important source of data in this study. What proved to be very revealing were the parts of the interviews in which young learners replied to the "why" questions: they were continually asked why they preferred or disliked something, how they knew they were better or worse than others, etc.

The results (Mihaljević Djigunović \& Lopriore, 2011) proved to be very revealing. They offered not only comparative evidence of attitudes and motivation in the seven contexts but also gave an insight into their development over the first four years of early learning. It was found that young learners' affective development was very complex and dynamic. Contrary to common belief, although young learners generally began their FL learning with a highly positive outlook, not all learners felt very positively at the start. About a quarter entertained neutral attitudes and a tiny minority did not enjoy learning the FL at all. The most preferred classroom activities were playing games and singing, but also learning new words, which proved to be one of the major sources of intrinsic motivation for most ELLiE participants. What they disliked referred mostly to the teacher's or peers' behaviour: they often felt the teacher did not call on them to answer questions as many times as they wished, or their peers did not obey the teacher, which they found unacceptable. Some disliked writing and drawing activities because, as they explained, their hand would hurt when they did these activities for too long. In contrast, sometimes young learners would claim in the interview that they, for example, liked a particular activity best, but in class they would be observed being completely off-task during that

4 The Netherlands did not participate in the scoping year. 
same activity. Information from the teachers solved the mystery and it became clear when a lack of focus meant a necessary respite from the demands of FL input and when it reflected a simple lack of interest. This goes to show that understanding motivational findings often requires triangulation and may benefit from a qualitative research approach. Changes in young learners' attitudes and motivation over the four years seemed to be also brought about by the novelty of new FL activities introduced in subsequent grades, or by the new school subjects scheduled in the curriculum. Negative developments were found to be connected to some learners' perception of the FL becoming increasingly complex as the first difficulties with FL learning itself emerged. With a growing awareness of school assessment criteria and an increasing ability to compare themselves to classmates, many young learners became more realistic in their self-perception of language learning outcomes. One interesting finding refers to the development of meta-learning ability: the ELLiE findings offer evidence that it can develop quite early, especially with some children. Once such awareness has developed, young learners become aware of and can express their FL learning needs. Drawing on the ELLiE data, it seems that during the early years what young FL learners need is a teaching approach that secures structure and guidance, gives enough space for concentration during activities, and provides learners with as much teacher attention as they need.

One special feature of the ELLiE project is the case studies of those learners that were focused on more deeply during the four years $(\mathrm{N}=271)$. Their profiles are still in the making. Those that have already been made (Mihaljević Djigunović, 2012; Mihaljević Djigunović \& Lopriore, 2011) testify to how dynamic young learner affective development is. They also suggest that the case study approach has great potential for understanding the multi-layered complexity of early FL learning.

\section{Discussion and a look into the future}

The findings of the studies reviewed above offer convincing evidence of both the relevance and complexity of research into young FL learners' attitudes and motivation. They also suggest that, besides sharing some features of attitudes and motivation with all learners and specifically with those of older FL learners, young FL learner attitudes and motivation are phenomena that have a distinct nature and require a specific approach. In this section, we will discuss the main issues raised by the studies and consider some new avenues that, in our view, may lead to furthering our understanding of these important learner factors through future research. 
We would first like to focus on how the research we described contributed to changes in understanding the role of attitudes and motivation in early FL learning. Based on the analysed European studies, a shift can be noticed from considering positive attitudes and motivation as a cause of FL achievement to seeing it as an outcome of early learning. Initially, positive correlations between motivation and achievement established in quantitative studies were often uncritically interpreted as evidence of a causal relationship: positive attitudes and high motivation were the reason why a learner was successful. Burstall's (1975) claim that 'nothing succeeds like success', suggesting that achievement may lead to positive attitudes and high motivation (but not necessarily the other way round), initiated a different approach to the interpretation of possible causal relationships. In time, this new interpretation of findings coincided with an increasing awareness of the multilingual and multicultural character of the European context. Recent documents on language policies in Europe (e.g., the Commission of the European Communities, 2003; the Council of Europe, 2007; the European Parliament, 2009) explicitly state that positive attitudes to other languages, cultures and people are among the advantages of early FL learning. This also shows that FL learning success is now defined more broadly as well as differently. In contrast, in the 1970s language learning achievement was basically defined and measured in terms of the number of linguistic structures young learners managed to master over a particular learning period, which lead to disillusionment in some stakeholders and, in some contexts (e.g., Britain), to deciding against early FL learning.

Interest in research into individual differences (e.g., Dörnyei, 2005; Robinson, 2002) also contributed to broadening the scope of attitudinal and motivational investigations. Once it was realised that individual learner differences are not completely independent variables but interact with one another, the relationship of attitudes and motivation with achievement could be interpreted taking into account their interactions with such factors as language learning styles and strategies, learner beliefs, self-concept etc. Although we still lack a model of young learner attitudes and motivation that would comprise all relevant relationships with other individual variables, we are coming closer to understanding the complexity of their joint impact on language achievement. This is also true about the impact of contextual variables. Another important insight that emerges from the studies discussed in this paper is that attitudes and motivation may not only interact with a host of other individual learner variables and with contextual variables, but their interactions change with learners' age. This is a major contribution of the research to date that needs to be kept in mind by both researchers and practising teachers alike. From the theoretical 
point of view, a model that could reflect young FL learner attitudes and motivation would need to be sufficiently comprehensive in terms of the variables it would be based on as well as in terms of their dynamic relationships. From the teaching point of view, it is extremely important that teachers understand how and why their learners' motivation changes over time so that they may be able to arouse and maintain it successfully through appropriate motivational teaching strategies.

Contributions can be noticed at the level of research methodology as well. Qualitative approaches are now being increasingly used alongside quantitative ones, and mixed methods are close to becoming common practice. Of particular interest as well as benefit is the trend found in some studies to consider the young learner as an important source of data. These developments have contributed in important ways to extending the concepts of young learner attitudes and motivation by offering evidence of how multi-dimensional and dynamic they are.

Although major progress can be noticed in studies on young learner attitudes and motivation, much remains to be done in this research subfield. It seems to us that the more recent research trends (combination of qualitative and quantitative methods, longitudinal approach) will also continue in the near future. However, it is our belief that before major new insights are obtained some reconceptualisations and research innovations may be necessary. At the conceptualisation level, we still lack a comprehensive understanding of young learner attitudes and motivation that could be a good basis for a valid theoretical model. The latest developments in motivational research have concerned mostly older learners (e.g., L2 motivational self-system) and have not yet been applied on younger children. It is possible that, age being a key factor in FL learning, young learner motivation needs to be conceptualised differently from older learner motivation. As the studies reviewed here show, different variables emerge or become salient in early FL learning compared to later learning. One particular aspect of young FL learner motivation that has not been considered is its fluctuation during lessons. As any teacher can observe, young learner motivation is subject to extreme changes in intensity during a single lesson, almost on a minute-to-minute basis. Studies into what precisely is responsible for these fluctuations and into their possible patterns are practically non-existent, even with more mature learners, except for a recent study by Pawlak (2012), carried out with Polish teenage learners. Future research should focus on what constitutes young FL learner motivation and what interactions it enters into with other relevant factors; only the findings of systematic research in this direction could, we believe, throw light on its true relationship with language learning achievement. 
In order to be able to understand the causal relationships between attitudes and motivation with other variables, achievement included, we need more experimental studies. These are very hard to carry out; hence, there have been very few so far. However, they are indispensable if we want to fully understand the impact and explanatory potential of these apparently multifaceted learner factors. Another methodological challenge that future research will need to deal with concerns the complex issue of measuring the temporal variability of young learner motivation. This will require the development of new sophisticated and sensitive instruments, triangulation and longitudinal approach. Such high demands will probably make ecological validity of future studies another issue that will need to be resolved.

Finally, the impact of research findings on educational policies on early FL learning may become stronger in the future. In an increasing number of contexts, educational stakeholders are relying ever more on research to point them in the right direction. It may sound too optimistic to expect that such an approach will intensify and become common practice, but there is no harm in hoping so.

\section{References}

Bagarić, V. (2007). English and German learners' level of communicative competence in writing and speaking. Metodika, (8)1, 239-257

Bernaus, M., Cenoz, J. Espí, M. J., \& Lindsay, D. (1994). Evaluación del aprendizaje del inglés en niños de cuatro años: Influencias de las actitudes de los padres, profesores y tutores. [Assessment of EFL learning in four-year-old children. Impact of teacher, parent and gardian attitudes]. APAC of News, 20, 6-9.

Blondin, C., Candelier, M., Edelenbos, P., Johnstone, R., Kubanek-German, A., \& Taeschner, T. (1998). Foreign languages in primary and pre-school education. London: CILT.

Burstall, C. (1975). Primary French in the balance. Foreign Language Annals, 10(3), 245-252.

Chambers, G. (2000). Motivation and the learners of modern languages. In S. Green (Ed.), New perspectives on teaching and learning modern languages (pp. 46-76). Clevedon: Multilingual Matters. Clément, R., Dörnyei, Z., \& Noel, K. A. (1994). Motivation, self-confidence, and group cohesion in the foreign language classroom. Language learning, 44(3), 417-448.

Commission of the European Communities (2003). Promoting language learning and linguistic diversity: An action plan 2004-2006. Retreived 19.7.2012, from www.eu.int/comm/education/doc/ official/keydoc/actlang/act_lang_en.pdf

Csapó, B., \& Nikolov, M. (2002, April). The relationship between students' foreign language achievement and general thinking skills. Paper presented at the American Educational Research Association Annual Meeting, New Orleans, USA. 
Council of Europe (2007). From linguistic diversity to plurilingual education: Guide for the development of language education policies in Europe. Main version. Strasbourg: Council of Europe, Language Policy Division. Retreived 10.7.2012 from http://ec.europa.eu/education/doc/official/ keydoc/actlang/act_lang_en.pdf

Dörnyei, Z. (1990). Conceptualizing motivation in foreign language learning. Language Learning, $40(1), 45-78$.

Dörnyei, Z. (2005). The Psychology of the Language learner. Individual differences in second language acquisition. London: Lawrence Erlbaum Associates, Inc.

Dörnyei, Z., Csizér, K., \& Németh, N. (2006). Motivation, language attitudes, and globalisation: A Hungarian perspective. Clevedon: Multilingual Matters

Edelenbos, P., Johnstone, R., \& Kubanek, A. (2007). Languages for the children of Europe: Published research, good practice and main principles. Retreived 31.5.2011 from http//ec.europa,eu/education/ policies/lang/doc/youngsum_en.pdf

Enever, J. (Ed.) (2011). ELLiE: Early language learning in Europe. London, UK: The British Council. European Parliament (2009). Multilingualism: an asset for Europe and a shared commitment.

Retreived 11.7.2010 from http://www.europarl.europa.eu/sides/getDoc.do?pubRef=-//EP//

TEXT+TA+P6-TA-2009-0162+o+DOC+XML+Vo//EN

Gardner, R. C. (1985). Social psychology and second language learning: The role of attitudes and motivation. London, UK: Edward Arnold.

Gardner, R. C. (2010). Motivation and second language acquisition: the socio-educational model. New York: Peter Lang.

Gardner, R. C., \& Lambert, W. E. (1959). Motivational variables in second language acquisition.

Canadian Journal of Psychology, 13(4), 266-272.

Gardner, R. C., \& Lambert, W. E. (1972). The Attitude/Motivation Test Battery-revised manual. London, Ontario: The University of Western Ontario, Language Research Group.

Grahan, S. (2004). Giving up on modern foreign languages? Students' perceptions of learning French. The Modern Language Journal, 88, 171-191.

Harris, J., \& Conway, M. (2002). Modern languages in Irish primary schools. An evaluation of the National Pilot Project. Dublin: Institúid Teangeolaíochta Éireann.

Julkunen, K., \& Borzova, H. (1996). English language learning motivation in Joensuu and Petrozavodsk. Joensuu: University of Joensuu.

Lasagabaster, D. (2003). Attitudes towards English in the Basque Autonomous Community. World Englishes, 22, 585-597.

Limić, B. (1983). Motivacija za učenje stranog jezika [Motivation for FL learning]. Strani jezici, 3 , $150-156$.

Low, L., Brown, S., Johnstone, R., \& Pirrie, A. (1995). Foreign languages in primary schools evaluation of the Scottish pilot projects 1993-1995. Final report. Scottish CILT.

MacIntyre, P. D., Baker, S. C., Clément, R., \& Donovan, L. A. (2002). Sex and age effects on willingness to communicate, anxiety, perceived competence, and L2 motivation among junior high 
school French immersion students. Language Learning, 52(3), 537-564.

MacKey, A., \& Gass, S. M. (2005). Second language research. Methodology and design. Mahwah, New Jersey: Lawrence Erlbaum Associates Publishers.

Marschollek, A. (2002). Kognitive und affektive Flexibilität durch fremde Sprachen: eine empirische Untersuchung in der Primarstufe. [Cognitive and affective flexibility in foreign languages. Empirical study of first grade]. Münster: Lit.

Masgoret, A., \& Gardner, R. C. (2003). Attitudes, motivation, and second language learning: A metaanalysis of studies conducted by Gardner and associates. Language Learning, 53, 123-163.

Mihaljević Djigunović, J. (1998). Uloga afektivnih faktora u učenju stranoga jezika [Role of affective factors in FL learning]. Zagreb: Filozofski fakultet Sveučilišta u Zagrebu.

Mihaljević Djigunović, J. (2007). Afektivni profil, aspiracije i percepcija nastave hrvatskih učenika engleskog jezika [Croatian EFL learners' affective profile, aspirations and attitudes to English classes]. Metodika, 14, 115-126.

Mihaljević Djigunović, J. (2009). Impact of learning conditions on young FL learners' motivation. In M. Nikolov (Ed.), Early learning of modern foreign languages. Processes and outcomes (pp. 75-89). Bristol, UK: Multilingual Matters.

Mihaljević Djigunović, J. (2009, March). Learner behavior and learning outcomes: Insights from the YL classrooms. Paper presented at the American Association of Applied Linguistics conference, Denver, CO.

Mihaljević Djigunović, J. (2012). Early EFL learning in context - Evidence from a country case study.

London: The British Council.

Mihaljević Djigunović, J., \& Bagarić, V. (2007). A comparative study of attitudes and motivation of Croatian learners of English and German. SRAZ, 52, 259-281

Mihaljević Djigunović, J., \& Lopriore, L. (2011). The learner: do individual differences matter? In J. Enever (Ed.), ELLiE: Early language learning in Europe (pp. 29-45). London, UK: The British Council. Mihaljević Djigunović, J., \& Vilke, M. (2000). Eight Years After: Wishful thinking vs facts of life. In J. Moon \& M. Nikolov (Eds.), Research into teaching english to young learners (pp. 66-86). Pécs: University Press Pécs.

Nikolov, M. (1999). "Why do you learn English?” "Because the teacher is short": A study of Hungarian children's foreign language learning motivation. Language Teaching Research, 3(1), 33-65. Nikolov, M. (2002). Issues in English language education. Bern: Peter Lang.

Nikolov, M. (2003). Angolul és németül tanuló diákok nyelvtanulási attitűdje és motivációja.

[Attitudes and motivation of learners of English and German]. Iskolakultúra, 13(8), 61-73.

Nikolov, M. (2007, February). Early modern foreign language programmes and outcomes: factors contributing to achievements of Hungarian learners. Paper presented at TEMOLAYOLE conference, Pécs, Hungary.

Nikolov, M., \& Csapó, B. (2002) Twelve-year-olds' attitudes towards classroom activities and their performances on tests of English and German as a foreign language. American Association of Applied Linguists Annual Conference, Salt Lake City, U.S.A. 
Nikolov, M., \& Józsa, K. (2003). Idegen nyelvi készségek fejlettsége angol és német nyelvből a 6. és 10. évfolyamon a 2002/2003-as tanévben. [Factors influencing achievement in English and German as foreign languages]. Budapest: Országos Közoktatási Értékelési és Vizsgaközpont. Retreived from http://www.om.hu/letolt/okev/doc/orszmer2003/idegen_nyelv_beliv.pdf

Nikolov, M., \& Józsa, K. (2006). Relationships between language achievements in english and german and classroom-related variables. In M. Nikolov, \& J. Horváth (Eds.), UPRT 2006: Empirical studies in English applied linguistics (pp. 197-224). Pécs: Lingua Franca Csoport, PTE.

Olshtain, E., Shohamy, E., Kemp, K., \& Chatow, R. (1990). Factors predicting success in EFL among culturally different learners. Language Learning, 40, 23-44.

Pawlak, M. (2012).The dynamic nature of motivation in language learning: A classroom perspective. Studies in Second Language Learning and Teaching, 2(2), 249-278.

Pinter, A. (2011). Children learning second languages. Basingstoke, UK: Palgrave Macmillan. Robinson, P. (Ed.) (2002). Individual differences in instructed language learning. Amsterdam/ Philadelphia: John Benjamins Publishing Company.

Szpotowicz, M., Mihaljevic Djigunovic, J., \& Enever, J. (2009). Early Language Learning in Europe: a multinational, longitudinal study. In J. Enever, J. Moon \& U. Raman (Eds.), Young learner english language policy and implementation: International perspectives (pp. 141-147). Kent, UK: IATEFL. Tragant, E. (2006). Language learning motivation and age. In C. Muñoz (Ed.), Age and the rate of foreign language learning (pp. 237-276). Clevedon: Multilingual Matters.

Tragant, R., \& Muñoz, C. (200o). La motivación y su relación con la edad en un contexto escolar de aprendizaje de una lengua extranjera.[Motivation and its relationship to age in language learning in the school context]. In C. Muñoz (Ed.), Segundas Lenguas. Adquisición en el Aula (pp. 81-105).

Barcelona: Ariel.

Vilke, M. (1979). English as a foreign language at the age of eight. SRAZ, 24, 297-336.

Vilke, M. (1993). Early foreign language teaching in Croatian primary schools. In M. Vilke \& Y.

Vrhovac (Eds.), Children and foreign languages I (pp. 10-27). Zagreb: Faculty of Philosophy.

Vilke, M., \& Vrhovac, Y. (Eds.) (1993). Children and foreign languages I. Zagreb: Faculty of Philosophy.

Vilke, M., \& Vrhovac, Y. (Eds.) (1995). Children and foreign languages II. Zagreb: Faculty of Philosophy.

Vrhovac, Y. (Ed.) (1999). Strani jezik u osnovnoj školi [Foreign language in primary school]. Zagreb:

Naklada Ljevak.

Vrhovac, Y. (Ed.) (2001). Children and foreign languages III. Zagreb: Faculty of Philosophy.

Williams, M., Burden, R., \& Lanvers, U. (2002). 'French is the language of love and stuff': Student perceptions of issues related to motivation in learning a foreign language. British Educational Research Journal, 28(4), 504-528. 


\section{Biographical note}

Jelena Mihaljević Djigunović is Professor of SLA and TEFL at Zagreb University. Her main research interests include the age factor, affective learner variables, teaching English to young learners, and FL teacher education. She has participated in a number of international projects on language learning and teaching. The most recent project she has been involved in is the Early Language Learning in Europe (ELLiE) study, a longitudinal multi-national project carried out in seven European country contexts. She has published extensively in national and international journals. Her publications include three research books, several volumes that she co-edited, and over 100 research papers. 